Mycologia, 101(5), 2009, pp. 612-621. DOI: 10.3852/08-176

(C) 2009 by The Mycological Society of America, Lawrence, KS 66044-8897

\title{
Arbuscular mycorrhizae of dominant plant species in Yungas forests, Argentina
}

\author{
Alejandra G. Becerra ${ }^{1}$ \\ Instituto Multidisciplinario de Biología Vegetal \\ (CONICET), Cátedra de Diversidad Vegetal I, Facultad \\ de Ciencias Exactas, Físicas y Naturales, Universidad \\ Nacional de Córdoba, C.C. 495, 5000 Córdoba, \\ República Argentina \\ Marta Cabello ${ }^{2}$ \\ Instituto Spegazzini. Facultad de Ciencias Naturales y \\ Museo, Avenida 53, No. 477, 1900 La Plata, \\ República Argentina \\ Marcelo R. Zak ${ }^{3}$ \\ Instituto Multidisciplinario de Biología Vegetal, \\ Cátedra de Recursos Naturales y Gestión Ambiental, \\ Dpto. Geografía, Facultad de Filosofía y Humanidades. \\ C.C. 495, 5000 Córdoba, República Argentina \\ Norberto Bartoloni ${ }^{4}$ \\ Cátedra de Métodos Cuantitativos Aplicados, Facultad \\ de Agronomía, UBA, República Argentina
}

\begin{abstract}
In Argentina the Yungas forests are among the ecosystems most affected by human activity, with loss of biodiversity. To assess the arbuscular mycorrhizal (AM) colonization and the arbuscular mycorrhizal fungi (AMF) spore numbers in these ecosystems, the roots of the most dominant native plants (one tree, Alnus acuminata; three herbaceous, Duchesnea indica, Oxalis conorrhiza, Trifolium aff. repens; and one shrub, Sambucus peruviana) were studied throughout the year from two sites of Yungas forests. Assessments of mycorrhizal colonization (percent root length, intraradical structures) were made by washing and staining the roots. Soil samples of each plant species were pooled and subsamples were obtained to determine AM spore numbers. The herbaceous species formed both Arum- and Paris-type morphologies, whereas the tree and the shrub species formed respectively single structural types of Arumand Paris-type. AM colonization, intraradical fungi structures and AMF spore numbers displayed variation in species, seasons and sites. $D$. indica showed the highest AM colonization, whereas the highest spore numbers was observed in the rhizosphere of $A$. acuminata. No correlation was observed between spore numbers and root length percentage colonized

Accepted for publication 1 March 2009.

${ }^{1}$ Corresponding author. E-mail: beceale@gmail.com Phone-fax: $+54+351+4332104$

${ }^{2}$ Phone-fax: $+54+221+4258252$.

${ }^{3}$ Phone-fax: $+54+351+4332104$.

${ }^{4}$ Phone-fax: $+54+011+45248000$.
\end{abstract}

by AM fungi. Results of this study showed that Alnus acuminata is facultatively AM. The AM colonization, intraradical fungi structures and AMF spore numbers varied in species depending on phenological, climatic and edaphic conditions.

Key words: Alnus forests, AM intraradical structures, colonization-spore numbers correlation, montane cloud forest, seasonality

\section{INTRODUCTION}

Yungas forests have become some of the most widely affected ecosystems due to human activity, which has resulted in loss of biodiversity. To protect biodiversity, not only is it necessary to identify areas with large diversity of species, but it also is required that other areas should be preserved to maintain genetic and environmental variation (Brown et al 1993).

The montane cloud forest is one of the environmental units in Yungas forests. In this unit one of the most important plant communities is Alnus acuminata Kunth (Betulaceae) forests (Cabrera 1976). Alnus acuminata is tolerant to infertile soils, hence its ability to form ectomycorrhizal (ECM) (Becerra et al 2002, 2005a, b, c, d), arbuscular mycorrhizal (AM) (Becerra and Cabello 2007, Becerra et al 2007a) and actinorrhizal relationships with Frankia (Carú et al 2000), thus enabling it to fix atmospheric nitrogen in natural and disturbed soils (Cervantes and Rodríguez Barrueco 1992).

Alnus acuminata forests are monospecific as regards the tree stratum, with a high dominance of $95 \%$ (Bell 1991), whereas 186 species of shrubs and herbs compose the understory (Giusti et al 1996). Most of these plant species present symbiotic associations with arbuscular mycorrhizal fungi (AMF) (Becerra et al 2007b). These symbiotic associations, important for plant growth, succession and rehabilitation of deforested lands, are determined by features of the host plant and mycorrhizal fungus and regulated by soil and environmental factors (Janos 1996, Siqueira and Saggin-Júnior 2001). AM colonization usually promotes plant growth in natural ecosystems (Merryweather and Fitter 1995, Klironomos 2003) and AMF communities influence a number of important ecosystem processes, including plant productivity, plant diversity and soil structure (van der Heijden et al 1998, 2006; Vogelsang et al 2006).

Colonization rates are influenced by the placement and density of AM fungi propagules in soil, edaphic factors such as soil type and fertility, climatic factors 
such as soil temperature and moisture availability, host factors such as plant species and age of roots and fungal species identity (Cade-Menun et al 1991, Sanders and Fitter 1992, Sanders 1993). Differences in AMF communities have been found among plant species, ecosystems, locations and seasons (Bever et al 2001, Husband et al 2002, Öpik et al 2006) and also among parts of the root system.

Mycorrhizal diversity is considered an important factor in the establishment, survival and maintenance of plant community diversity (van der Heijden et al 1998, Smith et al 1999). Despite the important role played by mycorrhizal diversity in natural plant communities, little information is available on the AM dynamics in Yungas forests. The aim of this research was to study the AM colonization and AMF spore numbers of most dominant plant species from two sites of Yungas forests, analyze their morphological variation in fungal colonization and observe the presence of seasonal changes. This study will let us improve our knowledge on the ecology of Yungas forests and the mycorrhizal status of their dominant native plants.

\section{MATERIALS AND METHODS}

Research sites. - This study was carried out at two field sites in the Yungas in the northwestern region of Argentina (NWA), namely Quebrada del Portugués, Tafí del Valle (Tucumán Province) and Narváez Range (Catamarca Province). Details of the two study sites and phytosociological aspects have been reported by Becerra et al (2005d, 2007a). Results estimated from the Braun-Blanquet (1965) method, with an abundance scale of + to 5 , allowed the selection of the plant to be studied. Alnus acuminata Kunth was the dominant tree species studied (Braun-Blanquet: 4/5). Duchesnea indica (Andrews) Focke (Rosaceae) (Braun-Blanquet: 2), Oxalis conorrhiza Jacq. (Oxalidaceae) (Braun-Blanquet: 2) and Trifolium aff. repens L. (Fabaceae) (Braun-Blanquet: 2) were the dominant herbaceous understory plants studied, whereas Sambucus peruviana Kunth (Caprifoliaceae) (Braun-Blanquet: 1) was the dominant shrub sampled.

Sampling of soil and roots. - Sampling of soil and roots was conducted in both locations in autumn (May 2001, dry season), winter (Jul 2002, dry season), spring (Nov 2002, rainy season) and summer (Mar 2002, rainy season). In each zone (Quebrada del Portugués and Narváez Range) one homogeneous site $(30 \times 30 \mathrm{~m})$ was selected. In each site and during each season 10 samples of the dominant plant species were sampled. The root systems of all plants were carefully excavated to confirm connection between roots and shoots. The size of samples for A. acuminata trees and $S$. peruviana shrubs was $15 \times 15 \times 25$ (depth) $\mathrm{cm}$ because the majority of $A$. acuminata and $S$. peruviana roots occurred in the top $20 \mathrm{~cm}$ soil (Becerra et al 2005d). For herbs (D. indica, O. conorrhiza and T. aff. repens) the whole root system was sampled. The samples were placed in plastic bags and stored at $4 \mathrm{C}$.
Soil analysis. - Soil samples were air-dried and sieved (2 $\mathrm{mm}$ grid) and the $\leq 2 \mathrm{~mm}$ fraction was analyzed as follows. Electrical conductivity of a saturation extract was measured at $25 \mathrm{C}$ following Bower and Wilcox (1965). Field capacity was determined in a previously saturated sample of soil ( $1 \mathrm{~cm}$ thick), after being subjected to a centrifugal force of $1000 \times g 30 \mathrm{~min}$ (Veihmeyer and Hendrickson 1931). Soil $\mathrm{pH}$ was determined with a glass electrode in soil water relation 1: $2.5\left(\mathrm{w} \mathrm{w}^{-1}\right)$ (Peech 1965). Available phosphorus was determined with the method of Bray and Kurtz I (Jackson 1964) by relating spectral and standard absorbance of the sample. Organic matter content was determined following the method of Nelson and Sommers (1982). Total nitrogen was determined with the microKjeldhal method (Bremner and Mulvaney 1982).

Arbuscular mycorrhizal colonization.-Ten roots samples of each species were washed to remove soil and adhering organic particles. The root system of each plant was preserved with FAA and cleared and stained for observation (Phillips and Hayman 1970). Roots were cleared with $10 \% \mathrm{KOH}$ $(15 \mathrm{~min}$ at $90 \mathrm{C})$. Dark roots of $A$. acuminata and $S$. peruviana were bleached with $30 \% \mathrm{H}_{2} \mathrm{O}_{2}$ (5 min, room temperature). The roots were acidified with $1 \% \mathrm{HCl}(1 \mathrm{~min}$, room temperature) and stained in $0.05 \%$ trypan blue.

Root samples (ca. 25-30, $1 \mathrm{~cm}$ long) for A. acuminata were mounted on slides and viewed under a compound microscope at $400 \times$ (McGonigle et al 1990) due to the presence of an ectomycorrhizal mantle. The presence of AM fungal structures for each season and site was scored for 100 intersections of root and reticle line per plant. An intersection was considered mycorrhizal if the reticle intersected an arbuscule, a coil, a vesicle or an internal hypha attached to one of these structures. The colonization percentages were expressed as colonized intersects/total number of intersects $\times 100$.

In the case of herbs and shrubs 10 samples of 100 root segments $(1 \mathrm{~cm}$ long each) were analyzed for each season and site. Frequency of colonization and percentage of root length colonized (percent RLC) were quantified according to the grid-line intercept method (Giovannetti and Mosse 1980) under stereoscope-magnified Leica M 420. Ten colonized root fragments from herbs and shrubs of each sample $(n=100)$ were placed on slides, and the fungal intraradical structure, such as \% arbuscules, number of vesicles and entry points, was estimated according to Ocampo et al (1980). Quantification of AM root colonization was classified in these categories: very high $(>80 \%)$, high $(60-79 \%)$, medium $(40-59 \%)$, low $(20-39 \%)$ and very low (1-19\%), following Zangaro et al (2002).

AMF spore numbers. - Ten individual soil samples of plant species were pooled and thoroughly mixed. Three aliquots of $100 \mathrm{~g}$ soil were obtained for every plant species. Spores were extracted from soil samples by wet sieving and decanting (Gerdemann and Nicolson 1963), followed by centrifugation in water and in $80 \%$ sucrose solution (Walker et al 1982). A fine sieve $(38 \mu \mathrm{m})$ was used to collect the spores, and the coarse material remaining on the top sieve $(500 \mu \mathrm{m})$ also was checked for sporocarps and large spores. Only apparently healthy spores were counted under 
TABle I. Soil properties of the two sites, Quebrada del Portugués (QP, Tucumán) and Narvaéz Range (NR, Catamarca), as analyzed from soil profiles taken during field work

\begin{tabular}{lcc}
\hline \hline \multicolumn{1}{c}{ Parameters $^{\mathrm{a}}$} & Quebrada del Portugués & Narvaez Range \\
\hline Soil type & Epileptic Regosol Eutric & Haplic Regosol Eutric \\
FC (percent dry weight) & $21.51 \pm 2.12$ & $25.83 \pm 0.12^{*}$ \\
pH $1: 2.5$ & $5.65 \pm 0.38$ & $5.66 \pm 0.60$ \\
EC $\left(\mathrm{dS} \mathrm{m}^{-1}\right)$ & $0.30 \pm 0.24$ & $0.35 \pm 0.30$ \\
P $\left(\mathrm{mg} \mathrm{kg}^{-1}\right)$ & $13.75 \pm 4.98 *$ & $9.73 \pm 3.00$ \\
OM $(\%)$ & $0.21 \pm 0.08$ & $0.37 \pm 0.07 *$ \\
N $(\%)$ & $2.22 \pm 0.49$ & $3.65 \pm 0.79 *$ \\
Texture & Sandy loam & Loam \\
\hline
\end{tabular}

${ }^{a}$ Mean values of 20 samples. EC: electrical conductivity, FC: field capacity, P: available phosphorus, OM: organic matter, N: total nitrogen. Significance according to Tukey test indicated as $*(P<0.05)$.

stereomicroscope directly and recorded as mean spores per $100 \mathrm{~g}$ soil. Permanent slides of all spores were prepared by placing them in polyvinyl-lacto-glycerol (PVLG) and PVLG + Melzer's reagent. Spores were cracked open under the cover slip for observation of spore wall and inner wall characteristics.

Statistical analysis. - Data distribution of AM colonization and spore numbers was not normal (Kolmogorov-Smirnov and Shapiro-Wilks normatility tests), and variances were not homogeneously distributed (Levene test). Thus AM colonization percentages and AMF spore numbers were respectively arcsine and logarithmically transformed. ANOVA was performed to test the influence of the seasons and sites (Quebrada del Portugués and Narváez Range) on the AM root colonization and spore numbers in the studied plant species. ANOVA generated 40 mean values $(5$ hosts $\times 4$ seasons $\times 2$ site treatments), which was followed by the application of DGG multiple comparison Test (Di Rienzo, Guzmán and Casanoves test) to compare the means of the data (Di Rienzo et al 2002).

Variables of AM colonization (percent arbuscules, number of vesicles and entry points) were non-normal and the variances were not homogeneous. These variables were transformed into ranks and analyzed statistically by ANOVA, the equivalent to the nonparametric analyses (Zar 1999). DGC multiple comparison tests were applied (di Rienzo et al 2002). The relationships among AM colonization, intraradical AM fungal structures and AMF spore numbers for all plants, seasons and sites were analyzed by Pearson correlations.

\section{RESULTS}

Sites characterization.-Soils of Quebrada del Portugués (QP) are epileptic regosol eutric and Narváez Range (NR) are haplic regosol eutric (IUSS Working Group WRB 2006). Both soils were slightly acidic with low electrical conductivity but differed in texture and nutrient content (TABLE I). The soils from NR present higher contents of organic matter, total $\mathrm{N}$ and field capacity than QP, which had slightly higher levels of $\mathrm{P}$. The site at NR presented a lower mean annual precipitation than that at QP (698 and
$1350 \mathrm{~mm}$ respectively). Mean annual temperatures were similar at both locations, with $12 \mathrm{C}, 10 \mathrm{C}, 17 \mathrm{C}$ and $19 \mathrm{C}$ for autumn, winter, spring and summer respectively.

Root colonization and spore numbers.-Dominant plant species presented AMF structures in their roots. The herb roots presented terminal arbuscules, intra- and intercellular aseptate hyphae, coils and oval to rectangular intra- and intercellular vesicles (Arum- and Parismorphological type). Alnus acuminata presented intercellular aseptate hyphae and intra- and intercellular vesicles (Arum-type), while $S$. peruviana showed only intracellular hyphae and vesicles (Paris-type).

AM colonization and AMF spore numbers were similar in both sites $(P=0.404$ and $P=0.889$ respectively) although significant differences were found among seasons $(P<0.00001$ and $P<0.000001$ respectively) and hosts $(P<0.00001$ and $P<0.003$ respectively) (TABLE II). Significant tripartite interaction was observed, seasons $\times$ hosts $\times$ sites, for $\mathrm{AM}$ colonization and AMF spore numbers $(P<0.0001$ and $P<0.00001$ respectively), indicating that these variables fluctuated significantly between hosts among the two sites and the four seasons.

AM colonization percentages ranged from very low to medium. For NR they varied $3-37 \%$ and $5-44 \%$ at QP (TABLE III). With respect to plant species, in $A$. acuminata the AM colonization was very low (3-12\%); herbs presented different ranges of AM colonization, being low to medium (13-44\%) for D. indica; very low to low $(12-37 \%, 15-29 \%, 13-28 \%)$ for O. Conorrhiza, $T$. aff. repens and $S$. peruviana respectively (TABLE III). The highest AM colonization was observed in autumn, spring and summer (TABLE III). In both sites $O$. conorrhiza showed high AM colonization levels in autumn whereas A. acuminata showed high AM colonization levels in autumn and spring. In QP the highest AM colonization was observed in D. indica and in T. aff. repens in autumn. In NR the highest AM 
TABLE II. Percentage of AM colonization and AMF spore numbers of the studied species in both sites (Quebrada del Portugués and Narváez Range) in four seasons

\begin{tabular}{|c|c|c|}
\hline & Percentage of AM colonization ${ }^{a}$ & AMF spore density (spore/g dry soil) \\
\hline Alnus acuminata ${ }^{\mathrm{b}}$ & $7.19 \pm 8.10 \mathrm{c}$ & $529.62 \pm 362.43 \mathrm{a}$ \\
\hline Duchesnea indica & $25.71 \pm 12.71 \mathrm{a}$ & $364.62 \pm 171.10 \mathrm{~b}$ \\
\hline Oxalis conorrhiza & $23.89 \pm 10.81 \mathrm{a}$ & $371.21 \pm 182.63 \mathrm{~b}$ \\
\hline Trifolium aff. repens & $22.39 \pm 8.39 \mathrm{a}$ & $433.25 \pm 296.93 \mathrm{~b}$ \\
\hline Sambucus peruviana & $20.72 \pm 9.92 \mathrm{~b}$ & $511.54 \pm 451.90 \mathrm{~b}$ \\
\hline Quebrada del Portugués ${ }^{c}$ & $19.73 \pm 11.89 \mathrm{a}$ & $392.62 \pm 169.40 \mathrm{a}$ \\
\hline Narváez Range & $20.23 \pm 12.26 \mathrm{a}$ & $491.48 \pm 406.85 \mathrm{a}$ \\
\hline Autumn $(\text { dry season })^{d}$ & $26.18 \pm 14.46 \mathrm{a}$ & $498.46 \pm 272.90 \mathrm{~b}$ \\
\hline Winter (dry season) & $15.01 \pm 8.19 \mathrm{~d}$ & $241.17 \pm 81.48 \mathrm{c}$ \\
\hline Spring (rainy season) & $21.12 \pm 10.48 \mathrm{~b}$ & $782.27 \pm 336.44 \mathrm{a}$ \\
\hline Summer (rainy season) & $17.63 \pm 11.40 \mathrm{c}$ & $246.3 \pm 80.88 c$ \\
\hline
\end{tabular}

${ }^{\text {a }}$ Values are mean $\pm \mathrm{SE}$.

${ }^{\mathrm{b}}$ Mean of 80 samples and 24 samples for spore density.

${ }^{\mathrm{c}}$ Mean of 200 samples for AM colonization and 60 samples for spore density.

${ }^{\mathrm{d}}$ Mean of 100 samples for AM colonization and 30 samples for spore density. Values within columns followed by the same letter were not significantly different $(P<0.05)$.

colonization was observed during summer in $D$. indica and during autumn, winter and spring in $T$. aff. repens. D. indica was the herbaceous vegetation with the highest AM colonization. In NR, S. peruviana showed the highest AM colonization in spring and in QP during autumn and spring.

AMF spore numbers were 107-1329 per $100 \mathrm{~g}$ dry soil at NR site and 215-737 per $100 \mathrm{~g}$ dry soil at QP (TABLE III). In A. acuminata spore numbers were 1991329 per $100 \mathrm{~g}$ dry soil, in D. indica $220-737$ per $100 \mathrm{~g}$ dry soil, in O. conorrhiza $158-653$ per 100 g dry soil, in $T$. aff. repens 208-1125 per $100 \mathrm{~g}$ dry soil and in $S$. peruviana $107-1256$ per $100 \mathrm{~g}$ dry soil (TABLE III). The highest AMF spore numbers were observed in autumn and spring (TABLE III). At both sites D. indica showed the highest AMF spore numbers in spring, whereas $A$. acuminata and $T$. aff. repens in autumn and spring. In $O$. conorhiza and S. peruviana rhizospheres significantly higher AMF spore numbers were observed in autumn and spring in NR; however in QP higher AMF spore numbers were observed in spring.

Intraradical fungal structures.-Percentage of arbuscules differed significantly between sites, seasons and hosts. Significant interaction was observed among seasons and hosts $(P<0.001)$. In $D$. indica the highest percentage of arbuscules was observed in autumn and summer. Percent of arbuscules in $O$. conorrhiza and $T$. aff. repens respectively were higher in winter and autumn. No arbuscules were observed in A. acuminata and $S$. peruviana (TABLE IV). The number of vesicles differed significantly according to seasons, hosts and sites. Significant interaction was observed among hosts, seasons and sites $(P<0.01)$. In NR the number of vesicles was higher during autumn in A. acuminata, during winter and summer in D. indica, during summer in $O$. conorrhiza, during winter and autumn in $T$. aff. repens and during winter in S. peruviana. For QP the number of vesicles was higher during autumn in $A$. acuminata and $T$. aff. repens, during autumn and winter in D. indica and during winter in O. conorrhiza; no significant differences for $S$. peruviana were observed in any season (TABLE IV). The number of entry points also differed significantly according to sites, seasons and hosts. Significant interactions were observed among hosts and sites $(P<0.001)$ and seasons and hosts $(P<0.001)$. In $D$. indica the number of entry points was higher in spring and autumn, in $O$. conorrhiza during winter, spring and summer, in $T$. aff. repens during winter and spring and in S. peruviana during spring (TABLE IV).

Root colonization vs. spore number.-A positive correlation was observed between percentage of AM colonization and percentage of arbuscules $(r=$ $0.49 ; P<0.001)$, percentage of AM colonization and entry points $(r=0.59 ; P<0.001)$ and percentage of arbuscules and number of vesicles $(r=0.41 ; P<$ $0.01)$. No relationship was found between the percentage of AM colonization and spore density $(r$ $=0.06 ; P=0.76)$.

\section{DISCUSSION}

Soil characteristics of these forests were similar to Aceñolaza's (1995) results for A. acuminata forests in Tucumán Province and to observations for genus Alnus (Tarrant and Trappe 1971). 
TABLE III. Percentage of AM colonization (percentage AMC) and AMF spore number (AMF) for each host, sites (Quebrada del Portugués, QP; Narváez Range, NR) and seasons. Values are mean of 10 samples (for percentage AMC) and three samples $($ for $\mathrm{AMF}) \pm \mathrm{SE}$. Values within a row followed by the same letter were not significantly different for each host among seasons $(P<0.05)$

\begin{tabular}{|c|c|c|c|c|c|c|}
\hline Host & & Sites & $\begin{array}{c}\text { Autumn } \\
\text { (dry season) }\end{array}$ & $\begin{array}{c}\text { Winter } \\
\text { (dry season) }\end{array}$ & $\begin{array}{c}\text { Spring } \\
\text { (rainy season) }\end{array}$ & $\begin{array}{c}\text { Summer } \\
\text { (rainy season) }\end{array}$ \\
\hline \multirow[t]{4}{*}{ Alnus acuminata } & $\%$ AMC & QP & $12 \pm 14.2 \mathrm{a}$ & $5 \pm 4 b$ & $12 \pm 12.3 \mathrm{a}$ & $7 \pm 4.3 \mathrm{~b}$ \\
\hline & & NR & $7 \pm 3.4 \mathrm{a}$ & $3 \pm 6.3 \mathrm{~b}$ & $8 \pm 4.0 \mathrm{a}$ & $3 \pm 3.2 \mathrm{~b}$ \\
\hline & $\mathrm{AMF}$ & QP & $611.33 \pm 66.52 \mathrm{a}$ & $286.67 \pm 40.53 \mathrm{~b}$ & $604.33 \pm 73.32 \mathrm{a}$ & $298 \pm 73.08 \mathrm{~b}$ \\
\hline & & NR & $673.33 \pm 114.15 \mathrm{a}$ & $199.67 \pm 26.31 \mathrm{~b}$ & $1329.67 \pm 10.69 \mathrm{a}$ & $234 \pm 84.33 \mathrm{~b}$ \\
\hline \multirow{4}{*}{ Duchesnea indica } & $\%$ AMC & QP & $43.58 \pm 10.5 \mathrm{a}$ & $16.33 \pm 8.4 \mathrm{c}$ & $28.73 \pm 8.6 \mathrm{~b}$ & $22.98 \pm 10.5 b$ \\
\hline & & NR & $21.34 \pm 9.7 \mathrm{~b}$ & $13.72 \pm 3.7 \mathrm{c}$ & $25.22 \pm 7.3 \mathrm{~b}$ & $33.51 \pm 13.7 \mathrm{a}$ \\
\hline & $\mathrm{AMF}$ & QP & $315 \pm 28.83 b$ & $270.67 \pm 57.85 \mathrm{~b}$ & $737 \pm 72.64 \mathrm{a}$ & $220.33 \pm 68.70 \mathrm{~b}$ \\
\hline & & NR & $256 \pm 32 \mathrm{~b}$ & $248 \pm 39.68 \mathrm{~b}$ & $518.67 \pm 61.17 \mathrm{~b}$ & $264 \pm 21.17 \mathrm{~b}$ \\
\hline \multirow[t]{4}{*}{ Oxalis conorrhiza } & $\%$ AMC & QP & $36.13 \pm 11.57 \mathrm{a}$ & $19.81 \pm 4.19 \mathrm{~b}$ & $24.63 \pm 4.03 \mathrm{~b}$ & $12.55 \pm 4.66 \mathrm{c}$ \\
\hline & & NR & $36.46 \pm 12.01 \mathrm{a}$ & $18.89 \pm 5.78 \mathrm{~b}$ & $25.22 \pm 5.57 \mathrm{~b}$ & $17.42 \pm 6.89 \mathrm{c}$ \\
\hline & AMF & QP & $420.33 \pm 108.03 \mathrm{~b}$ & $378.67 \pm 57.85 \mathrm{~b}$ & $653.33 \pm 150.05 \mathrm{a}$ & $307.67 \pm 41.58 \mathrm{~b}$ \\
\hline & & NR & $358.33 \pm 45.08 \mathrm{a}$ & $158.67 \pm 17.95 \mathrm{~b}$ & $561.67 \pm 54.24 \mathrm{a}$ & $218.33 \pm 145.91 \mathrm{~b}$ \\
\hline \multirow{4}{*}{$\begin{array}{l}\text { Trifolium aff. } \\
\text { repens }\end{array}$} & $\% \mathrm{AMC}$ & QP & $28.87 \pm 9.13 \mathrm{a}$ & $16.07 \pm 5.37 \mathrm{~b}$ & $15.89 \pm 5.78 \mathrm{~b}$ & $26.85 \pm 6.49 \mathrm{a}$ \\
\hline & & NR & $27.78 \pm 6.16 \mathrm{a}$ & $23.29 \pm 6.24 \mathrm{a}$ & $22.57 \pm 8.71 \mathrm{a}$ & $17.83 \pm 7.83 \mathrm{~b}$ \\
\hline & $\mathrm{AMF}$ & QP & $374 \pm 91.24 \mathrm{a}$ & $256.33 \pm 33.56 \mathrm{~b}$ & $435.33 \pm 46.97 \mathrm{a}$ & $288.33 \pm 150.22 \mathrm{~b}$ \\
\hline & & NR & $538 \pm 59.92 \mathrm{a}$ & $239.67 \pm 52.72 \mathrm{~b}$ & $1125.67 \pm 140.74 \mathrm{a}$ & $208.67 \pm 48.05 \mathrm{~b}$ \\
\hline \multirow{4}{*}{$\begin{array}{l}\text { Sambucus } \\
\text { peruviana }\end{array}$} & $\%$ AMC & QP & $26.93 \pm 8.2 \mathrm{a}$ & $13.37 \pm 4.1 \mathrm{~b}$ & $20.93 \pm 5.0 \mathrm{a}$ & $15.63 \pm 8.4 \mathrm{~b}$ \\
\hline & & NR & $21.04 \pm 13.1 \mathrm{a}$ & $20.54 \pm 5.7 \mathrm{a}$ & $27.64 \pm 15.7 \mathrm{a}$ & $19.71 \pm 6.8 \mathrm{a}$ \\
\hline & $\mathrm{AMF}$ & QP & $313 \pm 49.24 \mathrm{~b}$ & $265.67 \pm 70.12 \mathrm{~b}$ & $600.67 \pm 41.86 \mathrm{a}$ & $215.67 \pm 52.17 \mathrm{~b}$ \\
\hline & & NR & $1125.33 \pm 351.58 \mathrm{a}$ & $107.67 \pm 53.89 \mathrm{~b}$ & $1256.33 \pm 362.44 \mathrm{a}$ & $208 \pm 75.42 \mathrm{~b}$ \\
\hline
\end{tabular}

Root colonization and spore numbers. - The present study reports the presence of AM colonization and AMF spore numbers in the rhizosphere of four dominant plant species in the Yungas forest, being also the first report for AM spore numbers for $A$. acuminata rhizosphere. Symbiotic associations with AMF were found in A. acuminata (Betulaceae), D. indica (Rosaceae), O. conorrhiza (Oxalidaceae), T. aff. repens (Fabaceae) and $S$. peruviana (Caprifoliaceae) in the Yungas. These species belong to families that are cited as mycorrhizal (Harley and Harley 1987, Wang and Qiu 2006). Based on findings by Carling and Brown (1982) and Yamato and Iwasaki (2002), these herb families can present Arum-Paris morphological types as well as other species of the same genus (Yamato 2004). The AM morphological type of $A$. acuminata is in accordance with results reported for these forests (Becerra et al 2007a).

The very low to medium percentages of AM colonization can be explained by high soil fertility observed in both sites. High soil fertility could indicate a low ability of the AM fungi to colonize the host species in accordance with Mejstrik (1973) and Hayman et al (1976). Nevertheless low AM colonization could reflect a low mycotrophic nature of the plant species analyzed (Ingleby et al 1997).

The range of AM colonization found in the plants (from $3 \%$ in A. acuminata to $44 \%$ in D. indica) is in agreement with Brundrett and Kendrick (1988), Smith and Read (1997) and van der Heijden et al (1998), who suggested that plants can differ in AM colonization. Very low AM colonization was found in $A$. acuminata, which then could be categorized as facultatively mycorrhizal $(<25 \%$ sensu Brundrett and Kendrick 1988). This condition can be explained by soil nutrient concentrations, the radical system and the physiology of the plant (Brundrett 1991, 2004). On the other hand, as stated by Berg et al (2001), low AM colonization might provide significant benefit to plants whereas increased colonization could increase the cost of carbohydrates to plants. Moreover the root length colonized by AM does not represent the quantity of living or active fungal structures in the nutrient transfer (Smith and Gianinazzi-Pearson 1990).

Mycorrhizas are three-way interactions of plants, fungi and soil (Brundrett 1991), thus environmental and edaphic factors are expected to affect their structure and function. The highest percentages of AM colonization were observed in autumn, spring and summer. These are the seasons where the greatest increase in root growth and mycorrhizal activity has been reported due to higher soil temperatures and adequate soil moisture (Brundrett and Abbott 1994). The level of AM intraradical colonization of a root segment can vary over days or weeks depending on factors influencing both fungal 
BECERRA ET AL: ARbUSCULAR MYCORRHIZAE IN THE YUNGAS

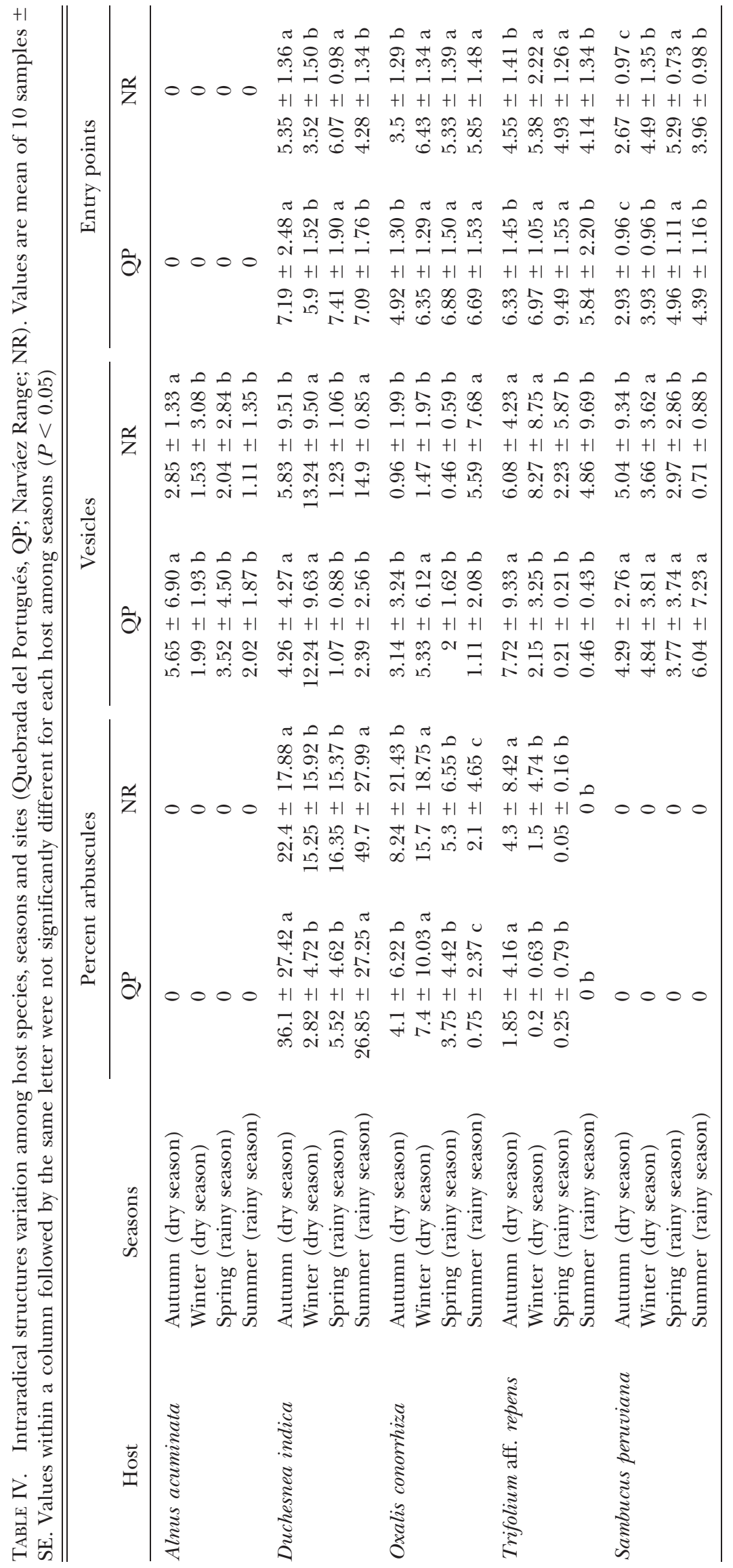


growth and root dynamics (Miller and Kling 2000). In this study (temperate region) host species present lower AM colonization levels, usually found in sites with high P. In general a good development of AM fungi is associated with a low concentration of soil nutrients (Gehring and Connell 2006).

AMF spore number in soils is variable (Smith and Read 1997). For both sites the total number of AMF spores was similar to those reported for tropical plantations (Cuenca and Meneses 1996) and tropical rain forests (Zhao et al 2001, Shi et al 2006). However, as Morton and Bentivenga (1994) suggest, a low AM fungal spore number does not mean absence of AM fungi. In tropical forests hyphae and root fragments colonized are the principal propagules in soils whereas AMF spores are the dormant state of these fungi (Janos 1996). The high humidity and fertility of Yungas soils might explain the low AMF sporulation, and the AM colonization could depend more on root fragments colonized and on the extraradical mycelium than on AM spores (Barea et al 1991).

In this study the higher AMF spore numbers observed during autumn and spring in all host species for both sites are in accordance with Clapp et al (1995) and Douds and Millner (1999) in forests sites, where a higher number of AMF spore number was observed during the period of maximum root growth. Ecological factors, such as seasonality, soil factors, host-dependence, age of the host plant, sporulation ability of AMF species in soils, could affect the development and distribution of AM fungi in the rhizosphere (Zhao 1999, Greipson and El-Mayas 2000, Lovelock et al 2003). Seasonal differences in AMF spore numbers probably reflect seasonal differences in spore formation, as Pringle and Bever (2002) stated.

Alnus acuminata's rhizosphere showed the highest AMF spore number and the lowest AM colonization. This could be explained by the fact that plant roots in forests are connected and therefore Glomalean spores might be found at some distance from the roots where they originated (Merryweather and Fitter 1998). The dominant understory species studied with a very low to medium AM colonization could influence the AMF sporulation of A. acuminata with a very low AM colonization, hence the higher sporulation observed in A. acuminata rhizosphere.

Intraradical fungal structures. - Intraradical fungal structures varied according to different seasons, hosts and sites. As stated by Ruotsalainen et al (2002) species-specific features as well as edaphic conditions might influence the development of AM colonization.

A clear AM colonization development-entry points-hyphae-arbuscules-vesicles-was not observed in this study. Instead of the highest occurrence of arbuscules found in spring, autumn and summer, the highest occurrence of vesicles and entry points in most plants was observed in cold dry seasons (autumn and winter), which confirms that the root system colonization by AMF is a dynamic process influenced not only by the growth and formation of infection units (spores, root fragments, hyphal networks) but also by the growth of the root system (Smith and Read 1997). The partitioning of fungal growth between intra- and extraradical structures is probably influenced by environmental or edaphic factors (e.g. soil temperature, soil moisture and soil fertility) as well as host responses to these factors (Brundrett 1991, Merryweather and Fitter 1998, Helgason et al 1999).

Colonization and $A M$ spore number correlation.-No correlation between spore numbers and percentage of AM colonization, and the wide range of spore numbers in the rhizosphere of studied plants were in line with results obtained by Zhao et al (2001), Liu and Wang (2003) and Zhang et al (2004). There are two possible explanations for our results. First, the roots associated with AM fungi might have decayed before sampling and, second, it is likely that some spores included in the counts were not viable or were present in clusters that functioned as one (inseparable) ineffective propagule in field soil (Jansa et al 2002). The relationship between AMF spore number and percentage of AM colonization is complicated, as Stutz and Morton (1996) suggested, and might be influenced by many environmental and biological factors (AM fungal species, plant host and soil nutrients).

In conclusion this first published report on the AM colonization and AMF spore number dynamics of dominant plant species of Yungas forests shows that these plants are very low to medium colonized; Alnus acuminata is facultatively AM (while presenting a high ectomycorrhizal colonization, Becerra et al 2005d); the AM colonization, intraradical fungi structures and AMF spore numbers in the plants vary depending on phenological, climatic and edaphic conditions. Further long-term studies are necessary to elucidate the ecological role of AM fungi in Yungas forests of Argentina.

\section{ACKNOWLEDGMENTS}

AGB is researcher of the Consejo Nacional de Investigaciones Científicas y Técnicas (CONICET). MNC is researcher from the Comisión de Investigaciones Científicas (CIC). We are grateful for the aid of anonymous reviewer, who provided constructive suggestions on our manuscript.

\section{LITERATURE CITED}

Aceñolaza PG. 1995. Estructura y Dinámica de bosques de aliso (Alnus acuminata HBK subsp. acuminata) de la 
Provincia de Tucumán [Doctoral dissertation]. National Univ Tucumán. Tucumán, Argentina. 286 p.

Barea JM, Azcón-Aguilar C, Ocampo JA, Azcón R. 1991. Morfología, anatomía y citología de las micorrizas arbusculares. In: Barea JM, Olivares J, eds. Fijación y movilización biológica de nutrientes. Vol. II. Madrid, Spain: CSIC. p 149-173.

Becerra A, Cabello M. 2007. Arbuscular mycorrhizas in Alnus acuminata (Betulaceae) seedlings inoculated with Glomus intraradices (Glomaceae). Bol Soc Arg Bot 42:155-158.

— 2002. Ectomycorrhizae between Alnus acuminata H.B.K. and Naucoria escharoides (Fr.:Fr.) Kummer from Argentina. Mycorrhiza 12:61-66.

—- Nouhra E, Daniele G, Domínguez L, McKay D. 2005a. Ectomycorrhizas of Cortinarius helodes and Gyrodon monticola with Alnus acuminata from Argentina. Mycorrhiza 15:7-15.

— Z Zak MR, Horton T, Micolini J. 2005b. Ectomycorrhizal and arbuscular mycorrhizal colonization of Alnus acuminata from Calilegua National Park (Argentina). Mycorrhiza 15:525-531.

—_, Beenken L, Pritsch K, Daniele G, Schloter M, Agerer R. 2005c. Anatomical and molecular characterization of Lactarius aff. omphaliformis, Russula alnijorullensis and Cortinarius tucumanensis ectomycorrhizae on Alnus acuminata. Mycologia 97:1047-1057.

—_, Pritsch K, Arrigo N, Palma M, Bartoloni N. 2005d. Ectomycorrhizal colonization of Alnus acuminata Kunth in northwestern Argentina in relation to season and soil parameters. Ann For Sci 62:325-332.

—- Arrigo NM, Bartoloni N, Domínguez LS, Cofré MN. 2007a. Arbuscular mycorrhizal colonization of Alnus acuminata Kunth in Northwestern Argentina in relation to season and soil parameters. Cienc Suelo 25:7-13.

- Cabello MN, Chiarini F. 2007b. Arbuscular mycorrhizal colonization of vascular plants from the Yungas forests, Argentina. Ann For Sci 64:765-772.

Bell DA. 1991. Distribución del bosque de Aliso del Cerro, Alnus acuminata (Betulaceae) en la Provincia de Tucumán, Argentina. Bol Soc Arg Bot 27:21-30.

Berg ES, Eaton GK, Ayres MP. 2001. Augmentation of AM fungi fails to ameliorate the adverse effects of temporal resource variation on a lettuce crop. Plant Soil 236: 251-262.

Bever JD, Schultz PA, Pringle A, Morton JB. 2001. Arbuscular mycorrhizal fungi: more diverse than meets the eye, and the ecological tale of why. BioScience 51:923-931.

Bower CA, Wilcox LW. 1965. Soluble salts. In: Black CA, ed. Methods in soil analysis: Agronomy No. 9, part 2. 1st ed. Madison, Wisconsin: Am Soc Agron Inc. p 933-951.

Braun-Blanquet J. 1965. Plant sociology: the study of plant communities. In: Fuller GD, Conard HS, eds. Transley review. London: Hafner. 439 p.

Bremner JM, Mulvaney CS. 1982. Nitrogen-total. In: Page AL, ed. Methods of soil analysis II. Madison, Wisconsin: Am Soc Agron.

Brown A, Placci G, Grau HR. 1993. Ecología y biodiversidad de las selvas subtropicales de Argentina. In: Goñi F,
Goin C, eds. Principios de política ambiental. Buenos Aires: Cámara de Diputados de la Provincia de Buenos Aires. p 215-222.

Brundrett M. 1991. Mycorrhizas in natural ecosystems. Adv Ecol Res 21:171-262.

- 2004. Diversity and classification of mycorrhizal associations. Biol Rev 79:473-495.

— Abbott LK. 1994. Mycorrhizal fungus propagules in the jarrah forest I. Seasonal study of inoculum levels. New Phytol 127:539-546.

— Kendrick B. 1988. The mycorrhizal status, root anatomy, and phenology of plants in a sugar maple forest. Can J Bot 66:1153-1173.

Cabrera AL. 1976. Fitogeografía de la República Argentina. Enciclo Argentina Agron Jardin 2:74.

Cade-Menun BJ, Berch SM, Bomke AA. 1991. Seasonal colonization of winter wheat in south coastal British Columbia by vesicular-arbuscular mycorrhizal fungi. Can J Bot 69:78-86.

Carling DE, Brown MF. 1982. Anatomy and physiology of vesicular-arbuscular and nonmycorrhizal roots. Phytopathol 72:1108-1113.

Carú M, Becerra A, Sepúlveda D, Cabello A. 2000. Isolation of infective and effective Frankia strains from root nodules of Alnus acuminata (Betulaceae). W J Microbiol Biotech 16:647-651.

Cervantes E, Rodríguez-Barrueco C. 1992. Relationships between the mycorrhizal and actinorhizal symbioses in non-legumes. In: Norris JR, Read DJ, Varma AK, eds. Methods in microbiology: techniques for the study of mycorrhizal. London: Academic Press. p 417-432.

Clapp JP, Young JPW, Merryweather JW, Fitter AH. 1995. Diversity of fungal symbiosis in arbuscular mycorrhizas from a natural community. New Phytol 130:259-265.

Cuenca G, Meneses E. 1996. Diversity patterns of arbuscular mycorrhizal fungi associated with cacao in Venezuela. Plant Soil 183:315-322.

di Rienzo JA, Balzarini M, Casanoves F, Gonzalez L, Tablada M, Guzmán W, Robledo CW. 2002. InfoStat versión 1.1. Univ Nac Córdoba, Argentina: Grupo InfoStat. Estadística y Biometría.

Douds DD, Millner PD. 1999. Biodiversity of arbuscular mycorrhizal fungi in agroecosystems. Agric Ecosyst Environ 74:77-93.

Gehring CA, Connell JH. 2006. Arbuscular mycorrhizal fungi in the tree seedlings of two Australian rain forests: occurrence, colonization and relationships with plant performance. Mycorrhiza 16:89-98.

Gerdemann JW, Nicolson TH. 1963. Spores of mycorrhizal Endogone species extracted from soil by wet sieving and decanting. Trans Brit Mycol Soc 84:679-684.

Giovannetti M, Mosse B. 1980. An evaluation of techniques for measuring vesicular-arbuscular mycorrhizal infection in roots. New Phytol 84:489-500.

Giusti L, Slanis A, Aceñolaza P. 1996. Fitosociología de los bosques de aliso (Alnus acuminata H.B.K. ssp. acuminata) de Tucumán (Argentina). Lilloa 38:93-120.

Greipson S, El-Mayas H. 2000. Arbuscular mycorrhizae of Leymus arenarius on coastal sands and reclamation sites 
in Iceland and response to inoculation. Rest Ecol 8: 144-150.

Harley JL, Harley EL. 1987. A check-list of mycorrhiza in the British flora. New Phytol 105:1-102.

Hayman DS, Barea JM, Azcón R. 1976. Vesicular-arbuscular mycorrhiza in southern Spain: its distribution in crops growing in soil of different fertility. Phytopathol Med 15:1-6.

Helgason T, Fitter AH, Young JPW. 1999. Molecular diversity of colonizing Hyacinthoides non-scripta (bluebell) in a semi-natural woodland. Mol Ecol 8:659-666.

Husband R, Herre EA, Turner SL, Gallery R, Young JPW. 2002. Molecular diversity of arbuscular mycorrhizal fungi and patterns of host associations over time and space in a tropical forest. Mol Ecol 11:2669-2679.

Ingleby K, Diagne O, Deans JD, Lindley DK, Neyra M, Ducousso M. 1997. Distribution of roots, arbuscular mycorrhizal colonisation and spores around fast-growing tree species in Senegal. For Ecol Manage 90:19-27.

IUSS Working Group WRB. 2006. World reference base for soil resources. 2nd ed. World Soil Resources Reports 103. FAO, Rome.

Jackson ML. 1964. Análisis químico de suelos. Barcelona, Spain: Ediciones Omega. 622 p.

Janos DP. 1996. Mycorrhizas, succession and the rehabilitation of deforested lands in the humid tropics. In: Frankland JC, Megan N, Gadd GM, eds. Fungi and environmental change. Cambridge, UK: Cambridge Univ Press. p 129-162.

Jansa J, Mozafar A, Anken T, Ruh R, Sanders R, Frossard E. 2002. Diversity and structure of AMF communities as affected by tillage in a temperate soil. Mycorrhiza 12: 225-234.

Klironomos JN. 2003. Variation in plant response to native and exotic arbuscular mycorrhizal fungi. Ecology 84: 2292-2301.

Liu RJ, Wang FY. 2003. Selection of appropriate host plants used in trap culture of arbuscular mycorrhizal fungi. New Phytol 115:495-501.

Lovelock CE, Andersen K, Morton JB. 2003. Arbuscular mycorrhizal communities in tropical forests are affected by host tree species and environment. Oecologia 135:268-279.

McGonigle TP, Miller MH, Evans DG, Fairchild GL, Swan JA. 1990. A method which gives an objective measure of colonization of roots by vesicular-arbuscular mycorrhizal fungi. New Phytol 115:495-501.

Mejstrik J. 1973. Advances in the study of vesiculararbuscular mycorrhiza. Ann Rev Phytopathol 11:171196.

Merryweather JW, Fitter AH. 1995. Arbuscular mycorrhiza and phosphorus as controlling factors in the life history of Hyacinthoides non-scripta (L.) Chouard ex Rothm. New Phytol 129:629-636.

1998. The arbuscular mycorrhizal fungi of Hyacinthoides non-scripta I. Diversity of fungal taxa. New Phytol 138:117-129.

Miller RM, Kling M. 2000. The importance of integration and scale in the arbuscular mycorrhizal symbiosis. Plant Soil 226:295-309.
Morton JB, Bentivenga SP. 1994. Levels of diversity in endomycorrhizal fungi (Glomales, Zygomycetes) and their role in defining taxonomic and nontaxonomic groups. Plant Soil 159:47-59.

Nelson DW, Sommers LE. 1982. Total carbon, organic carbon and organic matter. In: Page AL, Miller RH, Keeney DR, eds. Methods of soil analysis 2. Madison, Wisconsin: Am Soc Agron Inc. p 639-577.

Ocampo JA, Martín J, Hayman DS. 1980. Influence of plant interactions on vesicular-arbuscular mycorrhizal infection I. Host and non-host plants grown together. New Phytol 84:27-35.

Öpik M, Moora M, Liira J, Zobel M. 2006. Composition of root-colonizing arbuscular mycorrhizal fungal communities in different ecosystems around the globe. J Ecol 94:778-790.

Peech M. 1965. Hydrogen-ion activity. In: Black CA, ed. Methods in soil analysis: agronomy No. 9, Part 2. 1st ed. Madison, Wisconsin: Am Soc Agron Inc. p 914-926.

Phillips JM, Hayman DS. 1970. Improved procedures for clearing roots and staining parasitic and vesiculararbuscular mycorrhizal fungi for rapid assessment of infection. Trans Brit Mycol Soc 55:158-161.

Pringle A, Bever JD. 2002. Divergent phonologies may facilitate the coexistence of arbuscular mycorrhizal fungi in a North Carolina grassland. Am J Bot 89: 1439-1446.

Ruotsalainen AL, Väre H, Vestberg M. 2002. Seasonality of root fungal colonization in low-alpine herbs. Mycorrhiza 12:29-36.

Sanders IR. 1993. Temporal infectivity and specificity of vesicular-arbuscular mycorrhizas in co-existing grassland species. Oecologia 93:349-355.

- Fitter AH. 1992. The ecology and functioning of vesicular-arbuscular mycorrhizas in co-existing grassland species I. Seasonal patterns of mycorrhizal occurrence and morphology. New Phytol 120:517-524.

Shi ZY, Chen YL, Feng G, Liu RJ, Chrisite P, Li XL. 2006. Arbuscular mycorrhizal fungi associated with the Melicaceae on Hainan Island, China. Mycorrhiza 16: $81-87$.

Siquiera JO, Saggin-Júnior OJ. 2001. Dependency on arbuscular mycorrhizal fungi and responsiveness of some Brazilian native woody species. Mycorrhiza 11: 245-255.

Smith SE, Gianinazzi-Pearson V. 1990. Phosphate uptake and arbuscular activity in mycorrhizal Allium cepa L. Effects of photon irradiance and phosphate nutrition. Aust J Plant Physiol 17:177-188.

—, Read DJ. 1997. Mycorrhizal symbiosis. 2nd ed. London: Academic Press. 605 p.

Smith MD, Hartnett DC, Wilson GWT. 1999. Interacting influence of mycorrhizal symbiosis and competition on plant diversity in tallgrass prairie. Oecologia 121:574582.

Stutz JC, Morton JB. 1996. Successive pot cultures reveal high species richness of arbuscular endomycorrhizal fungi in arid ecosystems. J Bot 74:1883-1889.

Tarrant RF, Trappe J. 1971. The role of Alnus in improving the forest environment. Plant Soil 35:335-348. 
van der Heijden MGA, Klironomos JN, Ursic M, Moutoglis P, Streitwolf-Engel R, Boller T, Wiemken A, Sanders IR. 1998. Mycorrhizal fungal diversity determines plant biodiversity, ecosystem variability and productivity. Nature 396:69-72.

-, Streitwolf-Engel R, Riedl R, Siegrist S, Neudecker A, Ineichen K, Boller T, Wiemkem A, Sanders IR. 2006. The mycorrhizal contribution to plant productivity, plant nutrition and soil structure in experimental grassland. New Phytol 172:739-752.

Veihmeyer FJ, Hendrickson AH. 1931. The moisture equivalent as a measure of the field capacity of soils. Soil Sci 32:181-194.

Vogelsang KM, Reynolds HL, Bever JD. 2006. Mycorrhizal fungal identity and richness determine the diversity and productivity of a tallgrass prairie system. New Phytol 172:554-562.

Walker C, Mize W, McNabb HS. 1982. Populations of endogonaceous fungi at two populations in central Iowa. Can J Bot 60:2518-2529.

Wang B, Qiu Y-L. 2006. Phylogenetic distribution and evolution of mycorrhizas in land plants. Mycorrhiza 16: 299-363.
Yamato M. 2004. Morphological types of arbuscular mycorrhizal fungi in roots of weeds on vacant land. Mycorrhiza 14:127-131.

, Iwasaki M. 2002. Morphological types of arbuscular mycorrhizal fungi in roots of understory plants in Japanese deciduous broadleaved forests. Mycorrhiza 12:291-296.

Zangaro W, Nisizaki SMA, Domingos JCB, Nakano EM. 2002. Arbuscular mycorrhizal in native woody species of Tibagi River Basin, Paraná. Cerne 8:77-87.

Zar JH. 1999. Biostatistical analysis. New Jersey: Prentice Hall. 663 p.

Zhang ZW, Guo L-D, Liu R-J. 2004. Arbuscular mycorrhizal fungi associated with common pteridophytes in Dujiangyan, southwest China. Mycorrhiza 14:25-30.

Zhao ZW. 1999. Population composition and seasonal variation of VA mycorrhizal fungi spores in the rhizosphere soil of four pteridophytes. Acta Botan Yunn 21:437-441.

, Xia YM, Qin XZ, Li XW, Chen LZ, Sha T, Wang GH. 2001. Arbuscular mycorrhizal status of plants and the spore density of arbuscular mycorrhizal fungi in tropical rain forest of Xishuangbanna, southwest China. Mycorrhiza 11:159-162. 